\title{
Laboratory Examination in Hepatocelullar Carcinoma
}

\author{
Anggraini $\mathrm{D}^{1}$ \\ ${ }^{1}$ Departement of Clinical Pathology, Faculty of Medicine, Universitas Baiturrahmah, Padang, Indonesia \\ Email : debieanggraini@fk.unbrah.ac.id
}

\begin{abstract}
Hepatocellular carcinoma (HCC) is a malignant tumor originating from hepatocyte cells including primary malignant tumors of the epithelial liver. Hepatocellular carcinoma is the fifth most malignant in the world and the third largest cause of death of all malignancies. Diagnosis of HCC is obtained from the patient's history, examination of the patient, by imaging (ultrasonography, MRI or CT scan) and an increase in serum tumor biomarkers of alpha feto protein (AFP) (> $400 \mathrm{ng} \mathrm{mL}$ ). Early diagnosis is important to increase the patient's life expectancy and only $30-40 \%$ of patients are diagnosed at an early stage. Biomarkers in HCC not only help in diagnosing but also predict prognosis or recurrence and in choosing therapy. The stability of miRNA in blood circulation makes miRNA an ideal candidate for use in the diagnosis and treatment of cancer. Objective: to briefly review all current information about HCC. Conclusion: HCC diagnosis is obtained from the patient's history, physical examination, imaging (ultrasonic, MRI or CT scan that shows the presence of a typical liver mass for HCC) and an increase in AFP serum (> $400 \mathrm{ng} / \mathrm{mL}$ ). Biomarker examination and evaluation is still very limited, one of which is the examination of MicroRNAs
\end{abstract}

Katakunci - Biomarkers, hepatocelular carcinoma, microRNAs.

\begin{abstract}
Hepatocellular carcinoma (HCC) adalah tumor ganas yang berasal dari sel hepatosit termasuk tumor ganas primer hati epitel. Karsinoma hepatoseluler adalah yang paling ganas ke lima di dunia dan penyebab kematian terbesar ketiga dari semua keganasan. Diagnosis HCC diperoleh dari riwayat pasien, pemeriksaan pasien, dengan pencitraan (ultrasonografi, MRI atau CT scan) dan peningkatan biomarker tumor serum protein alpha feto protein $(A F P)$ (> $400 \mathrm{ng} \mathrm{mL}$ ). Diagnosis dini penting untuk meningkatkan harapan hidup pasien dan hanya 30-40\% pasien didiagnosis pada tahap awal. Biomarker di HCC tidak hanya membantu dalam mendiagnosis tetapi juga memprediksi prognosis atau rekurensi dan dalam memilih terapi. Stabilitas miRNA dalam sirkulasi darah menjadikan miRNA kandidat yang ideal untuk digunakan dalam diagnosis dan pengobatan kanker. Tujuan: Tujuan: untuk meninjau secara singkat semua informasi terkini tentang HCC. Kesimpulan: Diagnosis kanker hati didapat dari riwayat pasien, pemeriksaan fisik, pencitraan (ultrasonik, MRI atau CT scan yang menunjukkan adanya massa hati yang khas untuk kanker hati) dan peningkatan serum AFP (> $400 \mathrm{ng} / \mathrm{mL}$ ). Pemeriksaan dan evaluasi biomarker masih sangat terbatas, salah satunya adalah pemeriksaan MicroRNA
\end{abstract}

Keywords-Biomarker, Karsinoma Hepatoselular, mikroRNAs 


\section{INTRODUCTION}

Hepatocellular carcinoma (HCC) is a malignant tumor originating from hepatocyte cells, including primary malignant tumors of the liver epithelial ${ }^{1,2}$. Hepatocellular carcinoma accounts for $90 \%$ of primary liver cancer, which is the fifth most malignant in the world, and the third leading cause of death in all malignancies ${ }^{3}$. The annual incidence of HCC continues to increase in each country and it is estimated that there are 500,000 to one million cases each year, including Indonesia. ${ }^{4}$

\section{RISK FACTORS OF HEPATOCELULAR CARCINOMA}

Some risk factorsof HCC include hepatitis B and $\mathrm{C}$ virus infections ( $\mathrm{HBV}$ and $\mathrm{HCV}$ ), aflatoxin B1 exposure (AFB1), chronic alcohol abuse and metabolic syndrome ${ }^{5}$. About $54.4 \%$ of HCC cases are associated with HBV infection, so it is very interesting to examine the underlying mechanisms ${ }^{6}$. Three factors that influence the development of $\mathrm{HCC}$ in chronic HBV-infected individuals include the integration of viral DNA into the host cell genome, chronic inflammation due to the host's immune response to $\mathrm{HBV}$ infection and $\mathrm{HBx}$ protein which modulates the cellular signal transduction pathway ${ }^{7}$.

Hepatitis B virus $\mathrm{X}$ protein $(\mathrm{HBx})$ is a major regulator protein encoded by the $\mathrm{X}$-region HBV genome with a length of 154 amino acids, $17 \mathrm{kDa}$, which has an important role in the trans-activation of viral gene expression at the transcriptional level ${ }^{7,8,9}$. HBx protein can induce genetic changes in tumor suppressor genes and oncogenes and epigenetic aberrations in $\mathrm{HCC}^{7,8,10}$. $\mathrm{HBx}$ proteins regulate non-coding RNA (ncRNAs), consisting of microRNAs (miRNAs) and long non-coding RNA (lncRNA), which play a role in HBV-related hepatocarcinogenesis, modulate cell proliferation, cell cycle, anti-apoptosis, invasion and metastasis ${ }^{8,11}$.

\section{MicrornAs AND HEPATOCELULAR CARCINOMA}

MicroRNAs are small RNA molecules measuring 21-25 nucleotides, part of a noncoding RNA that acts as a regulator of postranscriptional gene expression at the level of mRNA, which regulates liver development and homeostasis 12.13,14,15. MiRNA dysfunction is strongly associated with the tumor process because HBx protein regulates ncRNAs including the MiRNA to act as an oncogen or tumor suppressor gene that can develop or inhibit cancer ${ }^{8,11}$. As a multifunctional protein, even though $\mathrm{HBx}$ protein does not have a DNA-binding domain, HBx protein can modulate ncRNAs indirectly, which interacts with various transcription factors such as p53, c-myc and nuclear factors kappa B and activates cellular signal transduction pathways, which change expression host genes and leads to the development of $\mathrm{HCC}^{5,7.9}$.

Tumor gene protein 53 (p53) is a transcription factor that is a tumor suppressor, has a multifunction in controlling DNA replication and repair, maintaining genomic stability, cell cycle progression and programmed cell death ${ }^{5,16}$. The presence of mutations and polymorphisms in p53, which cause tumor suppressors to become inactive, are often associated with the development of HCC in humans ${ }^{7,17}$, where $30 \%$ of cases of HCC are caused by mutations that cause inactivation of the p53 gene ${ }^{5}$. In addition, it was found that dysregulation of the p53 miRNA pathway in HCC would affect the expression of target mRNA involved in cell cycle regulation, apoptosis, angiogenesis, DNA repair and metastasis ${ }^{5,14,17}$.

Disregulation of the p53 miRNA pathway can have an oncogenic effect or eliminate tumor suppressor function in $\mathrm{HCC}^{14}$. Increased dysregulation of miRNA in HCC includes miR-221, miR-222 which causes tumor suppressor proteins p21, p27 and p57 to be suppressed, this will affect cyclins 
dependent kinase (CDK2) and cyclin $\mathrm{E}$ so that cell cycle development occurs in HCC ${ }^{14}$. In addition, anti-apoptotic molecules such as Bcl-2, Bcl-w, Bcl-xl and Mcl-1, modulated by miRNAs such as miR-122, miR-34a, miR $125 \mathrm{~b}$ and miR-let7, on HCC there is decreased dysregulation of these miRNAs resulting in failure to modulate the effects of anti-apoptotic molecules ${ }^{14}$.

The stability of miRNA in blood circulation makes miRNA an ideal candidate for use in the diagnosis and treatment of cancer ${ }^{17}$. The role of miR-221 in the pathogenesis of HCC has been widely reported, but in studies in China, differences in serum miR-221 levels in HCC patients and normal controls were not significant, so further research is needed to determine the diagnostic value of this miR-221 ${ }^{18}$.

Luo .'s research, et al. Stated that the sensitivity and specificity of miR-122 in HCC in China were $70.6 \%$ and $67.1 \%$ respectively, if miR-122 was combined with alpha-fetoprotein (AFP) serum, the sensitivity and specificity increased respectively. each being $87.1 \%$ and $98.8 \%{ }^{18}$. Hung's study, et al., The sensitivity and specificity of miR-let7 in HCC patients with chronic hepatitis B were $84.8 \%$ and $50 \%$, respectively ${ }^{19}$.

Bharali's study, et al., The sensitivity and specificity of miR-34a in HCC patients in India were $81.8 \%$ and $82.7 \%{ }^{20}$. respectively. Xu's research, et al. 2018 in China the sensitivity and specificity of miR-125b in HCC patients were $83 \%$ and $96 \%$, respectively ${ }^{21}$.

\section{Diagnosis of HePatocelular CARCINOMA}

Sensitive and specific initial diagnostic markers are needed to diagnose HCC, but at present the diagnosis is still dependent on serum alpha-fetoprotein (AFP) levels and ultrasonography (USG) ${ }^{18,22}$. High morbidity in $\mathrm{HCC}$ is associated with a lack of markers of early detection of the disease and very poor prognosis, thus limiting choices in chemotherapy, adjuvant therapy, or surgical procedures. Besides that, examination of AFP levels and ultrasound screening in HCC-suspected patients sometimes underdiagnosis and false positives ${ }^{18}$. Therefore, exploration in predictors of noninvasive early diagnosis of HCC 17,18,23 because early detection of HCC is very important for successful treatment and better patient survival ${ }^{18}$.

\section{CONCLUSION}

HCC diagnosis is obtained from the patient's history, physical examination, imaging (ultrasonic, MRI or CT scan that shows the presence of a typical liver mass for HCC) and an increase in AFP serum (> $400 \mathrm{ng} /$ $\mathrm{mL})$. Biomarker examination and evaluation is still very limited, one of which is the examination of MicroRNAs

\section{Daftar Pustaka}

[1] López P. Malignant Hepatic Neoplasms : Part 1 Hepatocellular carcinoma: the roles of liver biopsies and immunohistochemical studies and other important issues. 2015;462(1).

[2] Kruel CDP, Scaffaro LA. Review Article HEPATOCELLULAR CARCINOMA: DIAGNOSIS AND OPERATIVE MANAGEMENT. 2017;30(4):272-8.

[3] Hayes CN, Chayama K. MicroRNAs as Biomarkers for Liver Disease and Hepatocellular Carcinoma. 2016;

[4] Tenggara DA, Parkin M. BAB I PENDAHULUAN A . Latar Belakang Masalah. 2010;408(2005):1-16.

[5] Pollutri D, Gramantieri L, Bolondi L, Fornari F. TP53 / MicroRNA Interplay in Hepatocellular Carcinoma. 2016;1-20.

[6] Liu S, Koh SSY, Lee CGL. Hepatitis B Virus X Protein and Hepatocarcinogenesis. (Figure 1):114.

[7] Rawat S. Modulation of Apoptotic Signaling by the Hepatitis B Virus. 2014;(December 2012).

[8] Zhang B, Han S, Feng B, Chu X, Chen L, Wang $R$. Hepatitis $B$ virus $X$ protein-mediated noncoding RNA aberrations in the development of human hepatocellular carcinoma. 2017;49(2):e293-12. Available from: http://dx.doi.org/10.1038/emm.2016.177 
[9] Hcc H. T h e r a n o s t i c s MicroRNAs Associated With HBV Infection And. 2014;4(12).

[10] Lee YI, Hwang JM, Im JH, Lee YI, Kim NS, Kim DG, et al. Human Hepatitis B Virus-X Protein Alters Mitochondrial Function and Physiology in Human Liver Cells *. 2004;279(15):15460-71.

[11] Sun J, Lu H, Wang X, Jin H. MicroRNAs in Hepatocellular Carcinoma : Regulation, Function , and Clinical Implications. 2013;2013.

[12] Article R. MicroRNAs in Hepatocellular Carcinoma - Therapeutics and Beyond: A Systematic Review. 2017;

[13] Tan Y, Ge G, Pan T, Wen D, Chen L, Yu X, et al. A Serum MicroRNA Panel as Potential Biomarkers for Hepatocellular Carcinoma Related with Hepatitis B Virus. 2014;9(9).

[14] Sartorius K, Sartorius B, Chuturgoon AA. The biological and diagnostic role of miRNA' $\mathrm{s}$ in hepatocellular carcinoma. 2018;(March).

[15] Wang L, Yue Y, Wang X, Jin H. Function and clinical potential of microRNAs in hepatocellular carcinoma ( Review ). 2015;3345-53.

[16] Liu J, Zhang C, Zhao Y, Feng Z. MicroRNA control of p53. 2016;(January 2018).

[17] Sidhu K, Kapoor NR, Pandey V, Kumar V. The “ macro " world of microRNAs in hepatocellular carcinoma. 2015;5(March):1-8.

[18]Luo J, Chen M, Huang H, Yuan T, Zhang M, Zhang K, et al. Circulating microRNA-122a as a diagnostic marker for hepatocellular carcinoma. 2013;577-83.

[19] Hung C, Hu T, Lu S, Kuo F, Chen C, Wang J, et al. Circulating microRNAs as biomarkers for diagnosis of early hepatocellular carcinoma associated with hepatitis B virus. 2016;720:71420.

[20] Bharali D, Jebur HB, Baishya D, Kumar S. Expression Analysis of Serum microRNA-34a and microRNA-183 in Hepatocellular Carcinoma. 2018;(September).

[21] Xu L, Wei B, Hui H, Liu Y. Association of serum microRNA-125b and HBV-related hepatocellular carcinoma in Chinese Han patients. 2018;11(4):3699-703.

[22] Schütte K, Schulz C, Link A, Malfertheiner P, Schütte K, Schulz C, et al. Current biomarkers for hepatocellular carcinoma: Surveillance, diagnosis and prediction of prognosis. 2015;7(2):139-49.

[23] Lou J, Zhang L, Lv S. Biomarkers for Hepatocellular Carcinoma. 2017; 